\title{
GAMMA-RAY SPECTROMETRY AS A TOOL FOR MAPPING PETROGRAPHIC DOMAINS IN GRANITOIDS: THE EXAMPLES OF THE CUNHAPORANGA AND TRÊS CÓRREGOS GRANITIC COMPLEXES, PARANÁ STATE, SOUTHERN BRAZIL
}

\author{
Francisco J.F. Ferreira' ${ }^{1}$, Luiz Fornazzari Neto², Luizemara S.A. Szameitat ${ }^{3}$, Gilson B. Guimarães ${ }^{4}$, \\ Victor M. Oliveira Martin ${ }^{5}$, Hélcio Prazeres Filho ${ }^{6}$ and Horstpeter H. Ulbrich ${ }^{7}$
}

\begin{abstract}
The Aerogeophysical Project Serra do Mar Sul compiled gamma-ray data in the 70 's, for a large basement area $\left(50,000 \mathrm{~km}^{2}\right)$ in Paraná state, southern Brazil. The cps data were corrected in 1997 by BARMP, Brazil Airborne Radiometric Mapping Project, and are available now as TC (eU), K (\%), eTh and eU (in ppm). The data for the two large intrusions in the region, the Cunhaporanga Granitic Complex (CGC) and Três Córregos Granitic Complex (TCGC) were used to generate maps for $\mathrm{K}, \mathrm{eTh}$, eU, total counts, and several derived parameters: eTh/K, eU/K, eU/eTh, F. Contrasts between the two complexes are explained as a result of outcrop pattern and weathering (CGC more weathered than TCGC) and differences in overall Th content (eastern TCGC domains richer in the element), but a more uniform U distribution. The differences are enhanced in the eTh/K map (TCGC with lower ratios). The late alaskitic Serra do Carambei intrusion in the CGC shows the highest Th and U values. Gamma-ray patterns in granites subjected to strong subtropical alterations, with heavy seasonal rains, are more difficult to interpret, considering the possibility of strong leaching of $\mathrm{K}$ by weathering, and also supergene mobility of $\mathrm{U}$, factors that are absent, or less important, in areas with drier climates. The gamma-ray patterns of the three elements are influenced by their original distribution in the granites, but can be drastically changed by late hydrothermal alteration and weathering.
\end{abstract}

Keywords: granitic complexes, gamma-ray spectrometric maps, BARMP.

RESUMO. 0 Projeto Aerogeofísico Serra do Mar Sul, da década de 70, gerou mapas gamaespectrométricos para uma região de $50.000 \mathrm{~km}^{2}$ de embasamento cristalino no Estado do Paraná, Brasil meridional. Valores em cps foram corrigidos para TC (eU), K (\%), eTh e eU (em ppm) no Brazil Airborne Radiometric Mapping Project, BARMP, em 1997. Dados para as grandes intrusões da região, os complexos Graníticos Cunhaporanga (CGC) e Três Córregos (TCGC), foram utilizados para gerar mapas de K, eTh, eU, contagem total e dos parâmetros eTh/K, eU/K, eU/eTh, F. Os contrastes entre os dois complexos são explicados pelo padrão de afloramentos e intemperismo (CGC mais intemperizado que TCGC) e diferenças no teor geral de Th (domínios leste do TCGC enriquecidos no elemento) mais que do U. Estas diferenças são salientadas no mapa eTh/K (TCGC com razões menores). 0 Granito Serra do Carambeí, uma intrusão alasquítica tardia no CGC, mostra os teores mais elevados de Th e U. Padrões de raios gama em granitos submetidos a um acentuado intemperismo subtropical (com fortes chuvas sazonais) são de interpretação mais difícil que os de regiões com climas mais secos, em razão da possibilidade de lixiviamento total de $\mathrm{K}$ por intemperismo, e mobilidade supêrgena do U. Esses mapas indicam o padrão geral de distribuição de K, Th e U, eventualmente com mudanças drásticas impostas por alteração hidrotermal e especialmente intemperismo.

Palavras-chave: complexos graníticos, mapas gamaespectrométricos, BARMP.

${ }_{1}^{1}$ UFPR/LPGA, Centro Politécnico, Departamento de Geologia, P.0. Box 19045, 81531-980 Curitiba, PR, Brazil. Phone: +55(41) 3361-3132

- E-mail: francisco.ferreira@ufpr.br

2Rua Deocleciano de Paula Xavier, 351, 82120-270 Curitiba, PR, Brazil. Phone: +55(41) 9229-2089/9627-0465 - E-mail: Ifneto1@hotmail.com

3 Petrobras S.A. - Exploração/Geofísica/Métodos Potenciais/Métodos Não Sísmicos, Avenida República do Chile, 330, $11^{\circ}$ andar, 20031-170 Rio de Janeiro, RJ, Brazil. Phone: +55(21) 2144-0020 - E-mail: luizemara@gmail.com

${ }^{4}$ UEPG, Departamento de Geociências, Avenida General Carlos Cavalcanti, 4748, 84030-900 Ponta Grossa, PR, Brazil. Phone: +55(42) 3220-3046

- E-mail: gilsonburigo@gmail.com

${ }^{5}$ CODESVASF - Companhia de Desenvolvimento dos Vales do São Francisco e do Parnaíba, Rua Presidente Dutra, 160, Centro, 56304-230 Petrolina, PE, Brazil. Phone: +55(87) 3866-7710/3866-7709 - E-mail: vicmartin6@hotmail.com

6 Votorantim Metais Ltda., Exploração Mineral, Rua Luiz Benezato, 500, Polo Multivias, Bairro Medeiros, 13212-161 Jundiaí, SP, Brazil. Phone: +55(94) 3326-1436 - E-mail: helcio.filho@vmetais.com.br

7 USP, Instituto de Geociências, Departamento de Mineralogia e Geotectônica, Rua do Lago, 562, 05508-080 São Paulo, SP, Brazil. Phone: +55(11) 3091-3994 - E-mail: labicp@usp.br 


\section{INTRODUCTION}

The Projeto Aerogeofísico Serra do Mar Sul (PASMS, Aerogeophysical Project Serra do Mar Sul) was planned by the CPRM (Companhia de Pesquisa de Recursos Minerais, acting as the Brazilian Geological Survey) in the 70's (CPRM, 1978), to perform a regional survey with aerogeophysical gamma-ray spectrometric and magnetometric methods of the central-eastern region of the state of Paraná, covering a large part of the so-called Ponta Grossa Arch (PGA), the dominant structure in the region (Fig. 1). The original aerogeophysical surveys (CPRM, 1978) did present several shortcomings, related to irregular superpositions in the flight lines, localization errors and differences in flight altitudes, in part because two different bases were selected for the survey, one in Santa Catarina state, the other in Paraná state, and were also handicapped because readings were expressed in cps, with no conversion into quantitative data. More recently, as the result of a cooperative project between CPRM and Canadian institutions (Misener et al., 1997), the original data of PASMS were corrected for microlevelling and cartographic positions, and converted from cps into TC (total counts, $\mu \mathrm{R} / \mathrm{hr}$ ) and equivalents of $\mathrm{U}$, Th and $\mathrm{K}$ (potassium as \%, and eU and eTh in ppm; BARMP, 1997). Conversion parameters, from cps to quantitative data, were as follows: $\mathrm{TC}=[\mathrm{cps},(\mu \mathrm{R} / \mathrm{hr})]=51.79$ (R stands for Roentgen, the special unit of measure of the ionization produced in air by $\mathrm{x}$-ray or gamma radiation), $\mathrm{K}(\mathrm{cps} / \%)=25.88$, eTh $(\mathrm{cps} / \mathrm{ppm})=$ 1.78, eU (cps/ppm) $=10.07$.

A first general evaluation of the regional gamma-ray spectrometric survey, still using only cps, was presented by Guimarães et al. (2001), with special emphasis on the features shown by the large intrusive units, the Cunhaporanga Granitic Complex (CGC) and the Três Córregos Granitic Complex (TCGC). Within the framework of the "Gamma-Spectrometric Map Project of the Paraná Shield" (Ferreira \& Fornazzani Neto, 2005), and other related studies, financed partly by Mineropar (Minerais do Paraná S/A, the Geological Survey of Paraná) and also by Fapesp (São Paulo Science Foundation), we present here a study with emphasis on the petrographic variations that exist within the two large granitic complexes and the correlated response in gamma-ray patterns. It is pointed out that the method can yield values for $\mathrm{K}$, eU and eTh (in fresh rocks) that approach to a considerable extent the real figures as determined by chemical analysis, and are also valuable aids in mapping the faciological differences in granitic occurrences (see also previous abstract, Ferreira et al., 2005).

\section{METHODOLOGY}

A detailed description of field and calibration methods and data retrieval for gamma-ray spectrometric surveys can be found in
Grasty (1976), IAEA (1991), Minty (1997), Minty et al. (1997), Grasty et al. (1991, 1997), and Fornazzari Neto \& Ferreira (2003). In the present study, the data archives of the BARMP (1997) were used for the generation of the aerogeophysical data base. The evaluation of data focused on the areas occupied by the granitic intrusions, the CGC (with 23155 measurement points) and the GTC (with 27833 points; map with flight lines in Fig. 2), excluding data from the surrounding rocks. The readings include values taken both from fresh or altered granite blocks, and also from soils and alluvial deposits as well, the last ones widespread along the flood plain of the lapó river, in the inner regions of the CGC.

The Geosoft software was used for the purpose of selecting the screened data, and for obtaining color-graded maps. The observed spread of values, as well as mean figures, are indicated in Tables 1 and 2. Direct maps were prepared for TC (in $\mu \mathrm{R} / \mathrm{hr}$,), $\mathrm{K}$ (in \%), and eU and eTh (equivalents, in ppm), as well as maps derived from ratios such as eU/eTh, eTh/K, eU/K and the factor $\mathrm{F}$ (= K $\times$ eU/eTh; Gnojek \& Prichystal, 1985). Maps for the calculated factors $\mathrm{Kd}$ and $\mathrm{Ud}$ and the one showing the ternary values K-eU-eTh were also prepared (for a discussion, cf. Ulbrich et al., 2009; Ferreira et al., 2009, and bibliography therein). The $K d$ and $U d$ values are calculated as follows:

$$
\begin{aligned}
& K d=\frac{K_{s}-K_{i}}{K_{i}} \\
& U d=\frac{U_{s}-U_{i}}{U_{i}}
\end{aligned}
$$

where:

$$
\begin{aligned}
& K_{i}=\left(\text { mean } K_{s} / \text { mean } T h_{s}\right) \times T h_{s} \\
& U_{i}=\left(\text { mean } U_{s} / \text { mean } T h_{s}\right) \times T h_{s}
\end{aligned}
$$

$K_{s}$ and $U_{s}$ are the measured values at the station, and $K d$ and $U d$ are the relative deviations expressed as a fraction of the ideal station values. $K_{i}$ is the "ideal" thorium-defined potassium value for the station with the real value of $T h_{s}$, and $U_{i}$ is the "ideal" thorium-defined uranium value for that station (cf. Saunders et al., 1994, p. 413). These methods were first employed to define anomalies in oil fields (Saunders et al., 1987, 1993, 1994), to detect the possible migration of $\mathrm{K}$ and $\mathrm{U}$, on the basis of Thnormalized values of these two elements, assuming a more inert behavior shown by Th. The method was also expanded to detect migrations of $\mathrm{K}$, such as can be found in areas affected by hydrothermal alteration (Pires, 1995). The method is, however, more difficult to apply to granitic bodies with a relative variable abundance of Th, $\mathrm{U}$ and $\mathrm{K}$, since Th normalization may not be a satisfactory tool to search for $\mathrm{K}$ and $\mathrm{U}$ anomalies, especially in the 


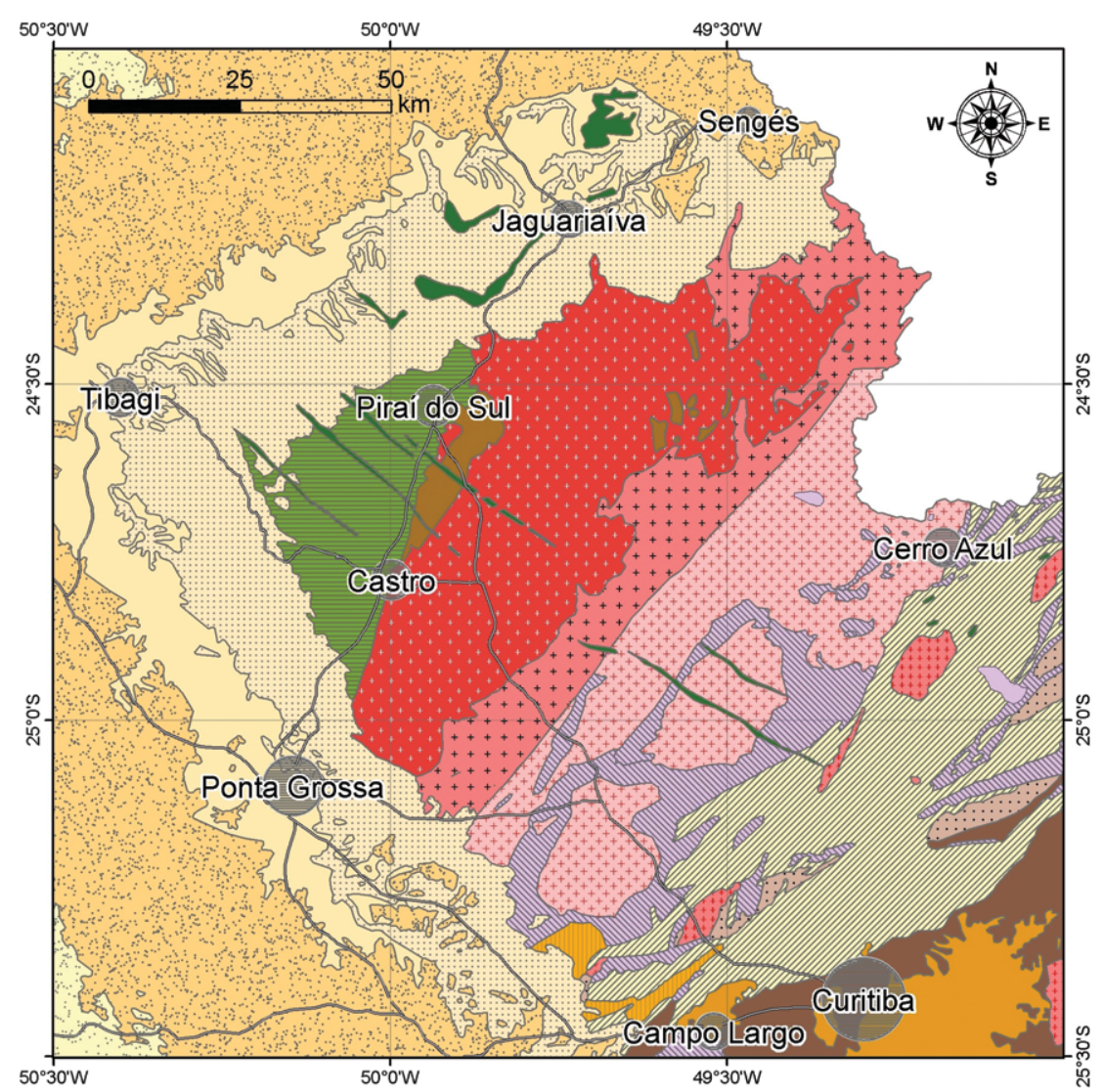

\section{Legend}

\begin{tabular}{|c|}
\hline Guabirotuba Group \\
\hline Alkaline massifs \\
\hline $\mathrm{Cr} 130 \mathrm{Ma}$ - Serra Geral Formation \\
\hline P - Passa Dois and Guatá Group \\
\hline PC - Itararé Group \\
\hline Dev - Ponta Grossa Formation \\
\hline Dev - Furnas Formation \\
\hline NP-Ca $530-600 \mathrm{Ma}$ - Camarinha Gro \\
\hline NP-Ca 540 Ma - Castro Group \\
\hline NP 590-570 Ma (?) - Granitoids \\
\hline
\end{tabular}

NP 610-590 Ma - Cunhaporanga Complex

$$
\text { NP - Três Córregos Complex }
$$

NP - Enclaves in Cunhaporanga Complex NP (?) - Açungui Group

++++
++++ NP $630 \mathrm{Ma}$ - Itaiacoca Group

MP 1500 Ma - Água Clara Formation

::::: PP 1752 Ma (?) - Apiaí Mirim Complex

Costeiro Complex

$\sim$ Roads

Cities
Brazil - Paraná State Location of area

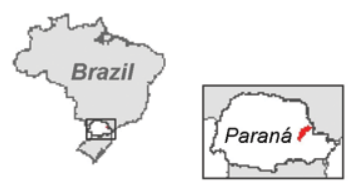

Figure 1 - Geologic map of the study area, Paraná state, southern Brazil, with the outline of the Ponta Grossa Arch (simplified, from Guimarães, 2000; Prazeres Filho, 2005).

case of granites, were accessory minerals may be concentrated in certain petrographic types, controlled by petrogenetic causes, and where $\mathrm{K}$ abundances can be, in addition, influenced by very local weathering conditions (e.g., strong leaching of $K$ from the centrally located granites in Cunhaporanga, much less so in the TCGC; cf. further discussion below).
Data were interpolated with the Geosoft system using a minimum curvature method (Briggs, 1974), taking for the colorgraded maps a standard grid of $500 \times 500 \mathrm{~m}$. The ArcGis system was used for the preparation of the geologic base maps, in order to compare the gamma-ray results with the distribution of granitic rocks. 


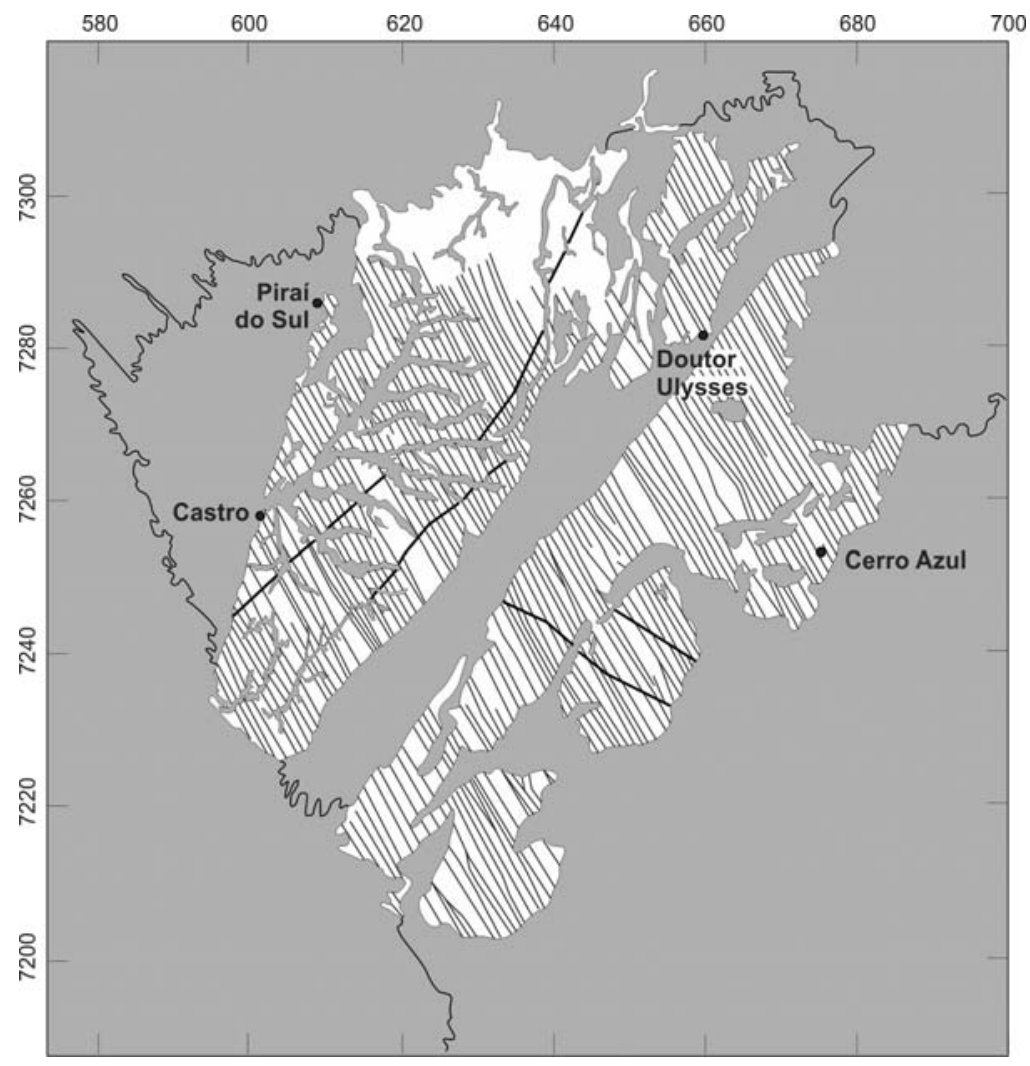

Figure 2 - Flight lines across the Cunhaporanga and Três Córregos complexes (Aerogeophysical Project Serra do Mar Sul; CPRM, 1978).

\section{REGIONAL GEOLOGY}

The basement area showing the outcrops of the CGC and TCGC is dominated by the large Ponta Grossa Arch (PGA), defined by a structural culmination with a N45W strike, limited to the W by the outcrop pattern of the basal sedimentary units of the Paraná Basin formations (general geological features in Fig. 1). The CGC shows outcrops covering about $3000 \mathrm{~km}^{2}$, entirely within Paraná state, while the TCGC covers about $5000 \mathrm{~km}^{2}$, a good part of it outcropping in São Paulo state, to the N. Both complexes show a general N30-40E elongation, parallel to the dominant structural trend in the basement areas of S-SE Brazil. Both granitic units are Neoproterozoic, the existing data indicating a strong overlap of ages (mostly 590-630 Ma for CGC versus 600-630 Ma for TCGC; Prazeres Filho et al., 2003; Prazeres Filho, 2005).

The Itaiacoca Group (or "Belt"), which separates the two large granitic complexes, presents deformed and metamorphosed carbonatic (mainly dolomitic) and pelitic units, with some minor intercalations of basic to intermediate volcanic lavas and intrusions. Greenschist facies metamorphism prevails, and the preserved structures (stromatolites, laminations, etc.), suggest that the Group represents former rather shallow platform deposits.
Detrital zircons show poorly constrained Neoproterozoic ages. The CGC is intrusive into the Itaiacoca Group, producing Iocal contact metamorphism and talc mineralizations (Szabó et al., 2006; Saunite et al., 2011). The extensive Itapirapuã shear zone (ISZ), one out of many large shear zones with a dominant NESW trend cutting the basement areas of SE Brazil, separates to the $E$ the Itaiacoca Group from the TCGC, the last one intrusive into the Mesoproterozoic Água Clara Formation (schists, amphibolites, etc., with a medium-grade metamorphism).

The Neoproterozoic to Early Cambrian Castro Group is constituted by sandstones, conglomerates and siltstones with intercalated rhyolitic and intermediate volcanic types, partially present as pyroclastic rocks. It outcrops to the W of the CGC, showing mainly tectonic contacts with nearby units. Farther $\mathrm{W}$, the sandstones of the Devonian Furnas Formation cover discordantly the Castro Group as well as units of the CGC, together with some underlying remnants of Ordovician diamictites belonging to the lapó Formation, the remnants of a widespread glaciation event in that area. The sedimentary units show a marked arcuate outcrop pattern (Fig. 1), indicating the strong structural influence on deposition patterns of the PGA, which probably began as early as 
Table 1 - Gamma-ray spectrometric mean values for different domains, CGC and TCGC.

\begin{tabular}{|c|c|c|c|c|c|}
\hline \multicolumn{6}{|c|}{ Mean values, domains in CGC } \\
\hline PD* & $\mathrm{TC}(\mathrm{eU})$ & $\mathrm{K}(\%)$ & eTh (ppm) & eU (ppm) & Samples \\
\hline 01 & 3.62 & 0.70 & 12.79 & 2.59 & 2577 \\
\hline 02 & - & - & - & - & - \\
\hline 03 & 4.74 & 0.89 & 16.22 & 2.84 & 3931 \\
\hline 04 & 4.51 & 0.63 & 18.58 & 1.87 & 8 \\
\hline 05 & 3.84 & 0.85 & 12.34 & 2.50 & 74 \\
\hline 06 & 4.53 & 1.48 & 9.72 & 2.82 & 1160 \\
\hline 07 & 4.45 & 0.54 & 19.11 & 3.41 & 2167 \\
\hline 08 & 4.99 & 1.10 & 14.40 & 2.86 & 1293 \\
\hline 09 & - & - & - & - & - \\
\hline 10 & 4.09 & 0.97 & 11.5 & 2.75 & 1077 \\
\hline 11 & 3.67 & 0.55 & 14.46 & 2.37 & 2589 \\
\hline 12 & 4.42 & 0.44 & 19.18 & 3.24 & 1001 \\
\hline 13 & 4.37 & 0.44 & 19.43 & 3.41 & 145 \\
\hline 14 & 3.83 & 0.44 & 14.97 & 3.06 & 1237 \\
\hline 15 & 4.51 & 0.38 & 20.22 & 3.13 & 2073 \\
\hline $16^{*}$ & - & - & - & - & - \\
\hline 17 & 4.87 & 1.39 & 10.24 & 2.89 & 518 \\
\hline $18^{*}$ & - & - & - & - & - \\
\hline 19 & - & - & - & - & - \\
\hline 20 & 5.35 & 1.49 & 12.10 & 3.42 & 37 \\
\hline 21 & 4.40 & 0.47 & 19.02 & 3.44 & 381 \\
\hline 22 & 7.69 & 0.38 & 36.22 & 6.34 & 348 \\
\hline $23^{*}$ & - & - & - & - & - \\
\hline 24 & 3.93 & 0.77 & 12.60 & 2.63 & 2499 \\
\hline \multicolumn{5}{|c|}{ Total number of sample points, CGC } & 23115 \\
\hline \multicolumn{6}{|c|}{${ }^{*}$ Domains 16,18 and 23 not represented in Figure 3} \\
\hline \multicolumn{6}{|c|}{ Mean values, domains in TCGC } \\
\hline PGSD* & $\mathrm{TC}(\mathrm{eU})$ & $K(\%)$ & eTh (ppm) & eU (ppm) & Samples \\
\hline $\bar{A}$ & 4.61 & 1.42 & 10.97 & 2.88 & 10777 \\
\hline B & 7.21 & 2.87 & 12.68 & 3.94 & 6289 \\
\hline C & 6.49 & 3.25 & 8.86 & 3.07 & 4220 \\
\hline D & 3.76 & 0.92 & 12.81 & 2.74 & 3898 \\
\hline E & 5.09 & 0.89 & 19.98 & 3.63 & 2219 \\
\hline $\mathrm{F}$ & 4.78 & 0.95 & 17.24 & 3.44 & 429 \\
\hline \multicolumn{5}{|c|}{ Total number of sample points, TCGC } & 27832 \\
\hline
\end{tabular}

PD: petrographic domains for CGC (for numbers, cf. Table 3); PGSD: petrographicgamma-ray spectrometric domains for TCGC (cf. text and Table 3).

the Devonian and extended up to, at least, the Neocretaceous. The axial culmination of the PGA, with the general N40-50W direction, is also the preferred intrusion site of the many diabase dikes that constitute the Ponta Grossa dike swarm. These rocks, showing ages around $130 \mathrm{Ma}$, are correlated with the vast Neocomian basaltic flows of the Serra Geral Formation, outcropping farther west, within the Paraná Basin (Marques \& Ernesto, 2004).

\section{Petrography of the granitic complexes}

The mentioned granitic complexes are composite batholiths, made up by several different intrusions. Both complexes incorporate significant portions of country rocks, sometimes as mappable units, the CGC showing large inclusions of the "Serra das Pedras Quartzite" (meta-sandstones and some arkoses), while the CGTC 
Table 2 - Minimum, maximum and mean values of gamma-ray spectrometric data for the whole CGC and TCGC ( $\mathrm{K}$ and $\mathrm{F}$ in \%, eTh and eU as ppm).

\begin{tabular}{|c|c|c|c|c|c|c|}
\hline \multirow{2}{*}{ Measured feature } & \multicolumn{2}{|c|}{ Lowest values } & \multicolumn{2}{c|}{ Mean values } & \multicolumn{2}{c|}{ Highest values } \\
\cline { 2 - 7 } & CGC & CGTC & CGC & CGTC & CGC & CGTC \\
\hline K & 0.00 & 0.01 & $\mathbf{0 . 6 8}$ & $\mathbf{1 . 9 1}$ & 3.96 & 6.28 \\
eTh & 0.00 & 0.04 & $\mathbf{1 5 . 1 4}$ & $\mathbf{1 2 . 1 0}$ & 78.40 & 92.17 \\
eU & 0.00 & 0.13 & $\mathbf{2 . 8 0}$ & $\mathbf{3 . 2 0}$ & 12.45 & 11.10 \\
eU/eTh & 0.00 & 0.04 & $\mathbf{0 . 1 9}$ & $\mathbf{0 . 2 9}$ & 2.48 & 68.75 \\
eTh/\%K & 0.00 & 0.01 & $\mathbf{4 4 . 6 4}$ & $\mathbf{1 1 . 3 9}$ & 3312 & 1555 \\
eU/\%K & 0.24 & 0.22 & $\mathbf{8 . 1 3}$ & $\mathbf{2 . 6 1}$ & 618 & 308 \\
F & 0.00 & 0.00 & $\mathbf{0 . 1 4}$ & $\mathbf{0 . 6 5}$ & 1.34 & 200.9 \\
\hline
\end{tabular}

* \% K figure normalized to 0.001 , when value was close to zero, or zero, for division purposes (cf. Ulbrich et al., 2009).

incorporates enclaves of schists, amphibolites and calc-silicate rocks mostly derived from the Água Clara Formation (Fuck et al., 1967; Guimarães, 2000; Prazeres Filho, 2005).

The CGC was mapped according to faciological criteria, grouping together rocks that show similarities in structure, texture, color, and mineral content, thus defining "facies associations" (Ulbrich et al., 2001), the final map presenting over 20 "petrographic units or domains" (PD 1 to 24); some areas are occupied by undifferentiated granites (Guimarães, 2000; cf. Table 3). Two late evolved granites are also included in the CGC, the Joaquim Murtinho unit (PD 19, about $10 \mathrm{~km}^{2}$, to the NW) and the ellipsoidal Serra do Carambeí Granite (PD 22, about 30 km², to the SW), the last one presenting a core area and an outer shell; the Joaquim Murtinho Granite is not included in the present study, because its outcrops are located outside the original spectrometric survey area. Outcrops in the CGC are usually few and distant, its central part largely covered by soils and the alluvial deposits of the lapó river. The distribution of the petrographic domains in the CGC is depicted in Figure 3 in a simplified way, showing only the outlines of the major petrographic units (source map for CGC in Guimarães, 2000; cf. Prazeres Filho, 2005, for the Três Córregos Granitic Complex).

The rocks of the CGC are mainly meta-aluminous calcalkaline granitoids (granodiorites to monzogranites, with titaniteamphibole-biotite as the predominant mafic association, sometimes only with titanite-biotite or biotite), mostly very similar in chemical composition. Peraluminous granitoids (with primary biotite and some muscovite) are concentrated along the eastern borders of the complex, chemically transitional to the calcalkaline types, while some more evolved syenogranites (with pegmatites) are present as irregular occurrences in the NE-part of the CGC. Feldspar-enriched "alaskites", with larger amounts of $\mathrm{K}$, Th and $\mathrm{U}$, make up the Joaquim Murtinho and the Serra do Carambeí granites. The predominant granitoids in the CGC correspond to "I" types, while the differentiated massifs represent "A" granites (e.g., Vlach et al., 1990; Guimarães, 2000; Prazeres Filho, 2005).

The PASMS covered areas up to the boundary between São Paulo and Paraná states, therefore leaving out the continuation of the TCGC into São Paulo, where this complex occupies an additional elongated area of about $80 \times 15-20 \mathrm{~km}$ (not included in Fig. 3).

The TCGC can also be divided into several faciological "units" (Prazeres Filho, 2005), equivalent to the "petrographic domains" mapped by Guimarães $(1995,2000)$ in the CGC. These "units" were defined on the basis of structure (deformed or massive), texture (equigranular or porphyritic; grain size) and mafic mineral content and distribution (cf. list in Table 3). They show an areal distribution that is closely reproduced by the "units" that can be observed in the gamma-ray spectrometric survey (Table 3, Fig. 3 , units $A$ to $F$ ).

Unit A shows predominantly deformed biotite-hornblende granites (monzogranites, granodiorites and quartz monzodiorites) with a protomylonitic structure; it corresponds to the western slice of the "Arrieiros-Cerro Azul Unit" (Prazeres Filho, 2005). Unit B (eastern part of the "Arrieiros-Cerro Azul Unit" of the same author) is constituted mainly by porphyritic biotite-hornblende granitoids (monzogranites, granodiorites and quartz monzodiorites) with an equigranular matrix. Unit C (the "São Sebastião Granite", an independent intrusion within the Água Clara Formation) is made up mainly by coarse-grained equigranular hornblende-biotite and biotite quartz monzonites, grading into a more coarser facies at the core area. Units D and $E$ (the "Conceição Granite or Unit" of Prazeres Filho, 2005) represent again an independent intru- 
Table 3 - Petrographic domains (PD) in the CGC and TCGC.

\begin{tabular}{|c|c|c|}
\hline PD & Petrographic domains and main rock types, CGC & Name $^{(1)}$ \\
\hline 01 & Grey hbl-bio grd to mgr, mainly porphyritic (M 7-25) & Abapã-Santa Quitéria \\
\hline 02 & Grey bio mgr to grd (5-15), rare mu-bio grd & Arroio das Pedrinhas \\
\hline 03 & Grey porphyritic hbl-bio mgr (M 10-20) & Biscaias-Boa Vista \\
\hline 04 & Cataclastic reddish bio granite, with fluorite & Espalha Brasa \\
\hline 05 & Grey hbl-bio mgr $(\mathrm{M} \sim 10)$ & Espigão Alto \\
\hline 06 & Md-grained mu-bio sgr-mgr $(\mathrm{M}<5)$, pegmatoid veins & $\begin{array}{l}\text { Francisco Simas (incl. Cunhaporanga } \\
\text { and Serra do Jacuzal) }\end{array}$ \\
\hline 07 & Grey porphyritic hbl-bio mgr to grd, massive or foliated (M 10-20) & Jotuba-Pitangui \\
\hline 08 & Porphyritic greyish-beige bio mgr to gdr (M 10-15) & Ouro Verde-Patrimônio Sto. Antônio \\
\hline 09 & Medium-grained grey bio mgr $(\mathrm{M} \sim 10)$ & Paredão da Santa \\
\hline 10 & Equigranular (mu)-bio mgr to grd, grey $(\mathrm{M} \sim 5)$ to rose $(\mathrm{M}<2)$ & Passo da Anta - Água Clara \\
\hline 11 & Grey hbl-bio mgr to dior, inequigranular to equigranular (M 10-25) & Piraí do Sul \\
\hline 12 & Fine to medium-grained greyish to rose bio mgr (M around 7 ) & Santa Rita \\
\hline 13 & Porphyritic hbl-bio grd to mgr (M 10-20), fine grained matrix & S. Abaixo - Alagados \\
\hline 14 & Grey equigranular hbl-bio grd to mgr (M 10-20) & S. Abaixo - Alagados \\
\hline 15 & Grey to whitish porphyritic bio granitoids (M 5-10) & Varginha \\
\hline $16^{*}$ & Undifferentiated domains (incorporated into domain 24) & Vila Branca \\
\hline 17 & Varied light-colored mu-bio granitoids (M 0-15); some hbl-bio mgr to grd & Limeira \\
\hline $18 *$ & Granitoids with metasediments (included into eastern outcrops of domain 6) & Cunhaporanga \\
\hline 19 & Cataclastic brown-reddish hematite K-feldspar granitoids $(\mathrm{M}<3)$ & Joaquim Murtinho \\
\hline 20 & Altered bio granitoids (M 7-10), with quartz veins, sulphides and fluorite & São Domingos \\
\hline 21 & Bio sgr (M 5-10), reddish, equigranular to porphyritic (core of structure) & Serra do Carambeí - red granitoids \\
\hline 22 & $\begin{array}{l}\text { Reddish bio granitoids, altered }(\mathrm{M}<3) \text {, fine- to coarse-grained, equigranular (border } \\
\text { facies) }\end{array}$ & Serra do Carambeí - altered granitoids \\
\hline $23^{*}$ & Inequigranular foliated bio mgr to grd (M 5-7) (incorporated into domain 6) & Serra do Jacuzal \\
\hline \multirow[t]{3}{*}{24} & Undifferentiated domains (few and sparse outcrops; includes Vila Branca) & Undifferentiated \\
\hline & *Domains 16, 18, 23 not represented in Figure 3 (included in other domains) & \\
\hline & "Gamma-ray-petrographic domains (cf. Table 1) and main rock types, TCGC & Name ${ }^{(2)}$ \\
\hline A & Bio-hbl mgr, grd, qmo, mostly deformed (protomylonitic) & Western part, Arrieiros-Cerro Azul Unit \\
\hline B & Grey bio-hbl mgr, grd, qmo, usually porphyritic (M 15-25) & Eastern part, Arrieiros-Cerro Azul Unit \\
\hline $\mathbf{C}$ & Grey hbl-bio qmo, bio qmo, coarse-grained (M 15-25), coarser at the center & São Sebastião Granite \\
\hline $\mathbf{D}$ & Rose-colored bio-hbl mgr (M 3-7) & $\begin{array}{l}\text { Vista Bonita facies, northern part of } \\
\text { Conceição Granite (Unit) }\end{array}$ \\
\hline $\mathbf{E}$ & $\begin{array}{l}\text { Hbl sgr to mgr, mafic enclaves, inequigranular (M 5-7), grey to rose-colored, with east- } \\
\text { ern rim of porphyritic types (M 10) }\end{array}$ & $\begin{array}{l}\text { Arroio Taquari facies, southern part of } \\
\text { Conceição Granite (Unit) }\end{array}$ \\
\hline $\mathbf{F}$ & Bio-hbl granitoids, strongly deformed (similar to A) & Southwestern strip of domain D \\
\hline
\end{tabular}

hbl: hornblende; bio: biotite; mu: muscovite; grd: granodiorite; mgr, sgr: monzogranite, syenogranite; qmo: quartz monzonite. M: color index

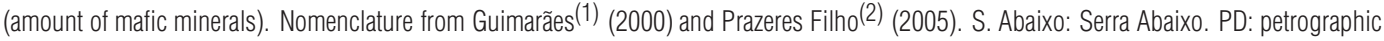
domains. For location, see Figure 3.

sion, with a northern part (Unit D, Fig. 3) showing predominant biotite \pm hornblende leuco-monzogranites, and a southern region (Unit E, Fig. 3) presenting inequigranular biotite-hornblende syenogranites to monzogranites. Farther west, a large area, closer to the ISZ and separated from the Conceição Granite by in- tervening Água Clara rocks, shows a gamma-ray spectrometric behavior identical to that observed for the northern Conceição Granite, and is here also defined as a part of Unit D (Fig. 3); this western section of Unit D corresponds to the southern outcrops of the deformed biotite-hornblende granitoids (the "Arrieiros-Cerro 


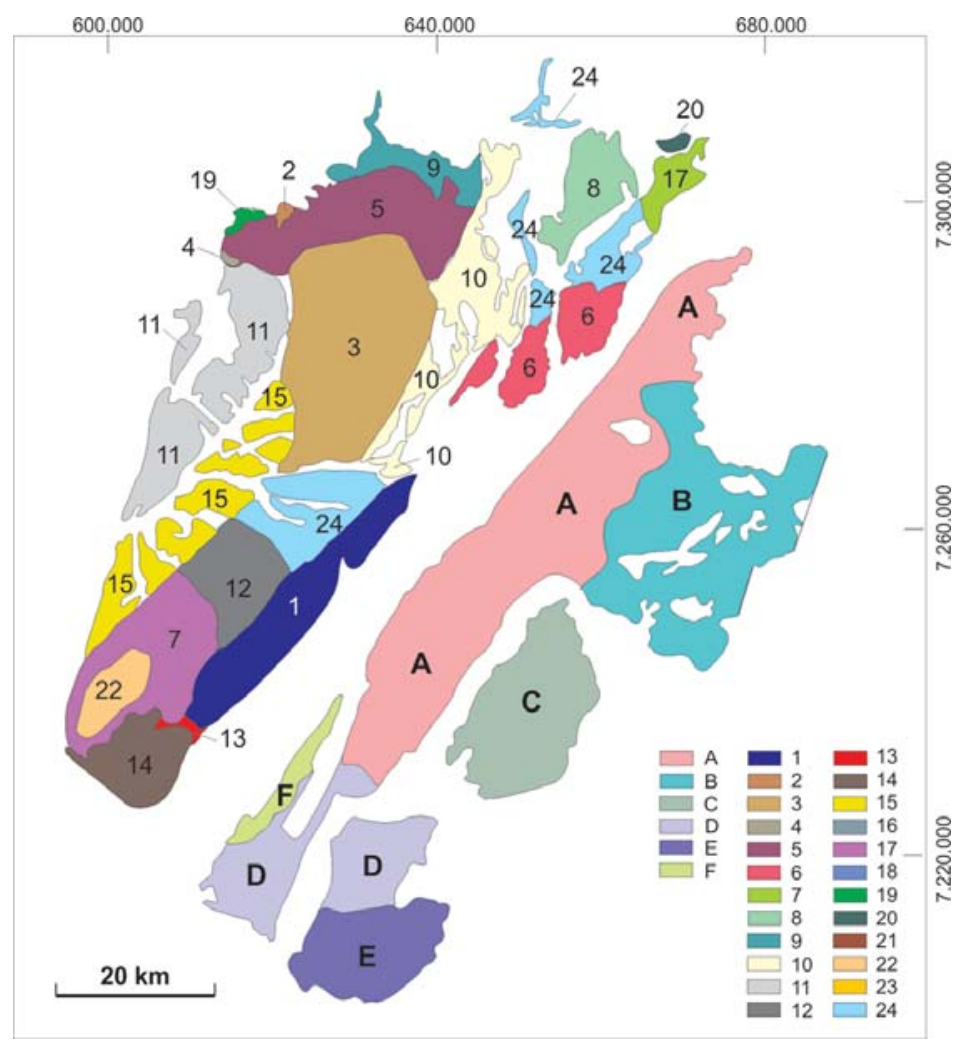

Figure 3 - Simplified map of petrographic domains in the CGC and of gamma-ray spectrometric domains in the TCGC (sources: Guimarães, 2000; Ferreira et al., 2005; Prazeres Filho, 2005).

Azul Unit" of Prazeres Filho), thus petrographically differing from the massive biotite \pm hornblende leuco-monzogranite that characterizes Unit $D$ in the northern part of the Conceição Granite (Fig. 3), probably representing a deformed counterpart of the massive leucomonzonites. Unit $F$ is a small slice of biotitehornblende granitoids, petrographically similar to rocks of Unit A, but with a more significant deformation, lying next to the ISZ (see below, for a discussion).

Chemically, most TCGC rocks are meta-aluminous calcalkaline granitoids, characterized by the mafic association biotitehornblende; primary muscovites, as well as more evolved granitic rocks, are absent from the TCGC (Prazeres Filho, 2005).

\section{RESULTS AND DISCUSSION}

Several patterns that were identified in the color-scale direct and derived maps confirm some general observations already presented in the earlier general evaluation (Guimarães et al., 2001). Maximum, minimum and mean values for $\mathrm{K}(\%)$, eTh and eU (in $\mathrm{ppm})$, as read from the gamma-ray survey, are listed in Table 1 (cf. also Table 2). Chemical data for $\mathrm{K}$, Th and $\mathrm{U}$ are known for over 100 granitoid rocks from both complexes; ranges and mean values are given in Table 4, which also lists variations and means observed worldwide in several types of granites.

The patterns observed in the CGC will be discussed first. The $\mathrm{K}$ map (Fig. 4) shows low to very low values, especially in the central part, where soil and alluvial covers are predominant, with some increase to a few percent $\mathrm{K}$ in the northern and northeastern sectors, as well as along a thin slice of granites which invade, in the central eastern region, the Itaiacoca Group (Fig. 4); interestingly, the evolved Serra do Carambeí Granite (PD 22, Fig. 3) is characterized also by very low $\mathrm{K}$ values, thus indicating that this K-rich granite had the element leached out by weathering. The eTh and eU maps are very different (Fig. 4). Several areas show strong Th concentrations, especially the Serra do Carambeí Granite. Thorium, with little chemical mobility during weathering, is most probably retained in "resistant" minerals in soils (for a discussion on the geochemical mobility of $\mathrm{U}$, Th and $\mathrm{K}$ under weathering, cf. Ulbrich et al., 2009). The U pattern shows the presence of the element in most of the CGC areas, possibly retained in soils (compare the eU and the $\mathrm{K}$ maps, the last one indicating strong leaching of $\mathrm{K}$ for almost the entire CGC, but a visible presence of 
Table $4-K$, Th and U compositional data for continental crust and granitoid rocks.

\begin{tabular}{|c|c|c|c|}
\hline Compositions & $\% \mathrm{~K}$ & ppm Th & ppm U \\
\hline Upper continental crust* & 2.60 & 10.5 & 2.7 \\
\hline Intermediate continental crust* & 1.91 & 6.5 & 1.3 \\
\hline Lower continental crust* & 0.51 & 1.2 & 0.2 \\
\hline Mean continental crust* & 1.50 & 5.6 & 1.3 \\
\hline $\mathrm{TTG}^{*}$ & 1.46 & 6.9 & 1.6 \\
\hline Granitoids, continental arc $(\mathrm{PRB})^{\star}$ & 1.62 & 7.2 & 1.5 \\
\hline Granitoids, oceanic arc* & 1.15 & 0.83 & 0.37 \\
\hline Himalayan leucogranitoids* & 3.68 & 5.0 & nd \\
\hline A-type granites $(L F B)^{*}$ & 3.43 & 19.7 & 5.0 \\
\hline Hornblende granites (LFB) ${ }^{\star}$ & 2.89 & 20 & 5.0 \\
\hline Cordierite granites (LFB)* & 3.40 & 19 & 5.0 \\
\hline Variations (calc-alkaline CGC) & $2.64-4.56$ & $7-47$ & $5-33$ \\
\hline Variations (calc-alkaline TCGC) & $1.58-4.03\left(3.18^{\star}\right)$ & $\sim 5-24\left(11.85^{\star}\right)$ & $\sim 2-4\left(2.43^{\star}\right)$ \\
\hline Variations (JMG) & $3.43-3.54$ & $20-27$ & $5.4-6.2$ \\
\hline Variations (SCG) & $3.28-3.72$ & $14-37^{* *}$ & $29-47^{* *}$ \\
\hline
\end{tabular}

*: mean values; ${ }^{* *}$ : preliminary values; nd: not determined; TTG: tonalites, trondjhemites, granites; PRB: Peninsular Range Batholith, California; LFB: Lachlan Fold Belt, SE Australia; JMG, SCG: Joaquim Murtinho and Serra do Carambeí differentiated granites in the CGC. Source: Guimarães (2000); Prazeres Filho (2000, 2005); Kemp \& Hawkesworth (2004); Rudnick \& Gao (2004); own data.

$U$ in at least a third of its surface, a situation that can be predicted, given the possibility of $\mathrm{U}$ retention in pedogenic compounds, in contrast to the possibility of total extraction of $\mathrm{K}$ under the same climatic conditions; cf. Ulbrich et al., 2009). In both eTh and eU maps, the ellipsoidal area of the Serra do Carambeí Granite is very clearly marked, as is also, with very low values, the dendritic outcrop pattern of the alluvial deposits of the lapó river (much enhanced, though, in the eU map, which suggests that Th-bearing phases may be present even in alluvial deposits and soil cover; compare eU and eTh maps in Fig. 4). On the other hand, the strip of CGC with peraluminous granitoids (holding both primary muscovite as well as biotite; PD 1, Fig. 3) adjacent to the Itaiacoca Group, presents very low $U$ and Th concentrations, although $\mathrm{K}$ is clearly present, an indication that these granites have low abundances of accessory minerals hosting $\mathrm{U}$ and $\mathrm{Th}$ (cf. the $\mathrm{K}$, eTh and eU maps in Fig. 4). The TC map (expressed as $\mu \mathrm{R} / \mathrm{hr}$ ) repeats the pattern of the eU map, again clearly indicating the position of the Serra do Carambeí Granite and the dendritic anomalies with low values depicting the site of the lapó alluvial deposits (Fig. 4).

In the derived maps for CGC observed in Figure 5 (especially in the $\mathrm{eU} / \mathrm{K}$ and eTh/K maps) it is again clear that weathering leaches out $\mathrm{K}$, leaving behind, to a large extent, the $\mathrm{U}$ and Thholding compounds, the first element probably retained within new pedogenic phases or as an absorbed cation in soil parti- cles, the second one preferably included within "resistant" primary phases in soils (cf. Ulbrich et al., 2009). It should be observed that the absolute values calculated for these maps depend on the minimum value that is defined for the $\mathrm{K}$ values (in order to inhibit a zero division), but clearly shows a surplus abundance of Th over $\mathrm{U}$, as is usual in most granitoids worldwide (cf. Table 4). Very low values are predominant in the eU/eTh map for the CGC, to a good extent controlled by the presence of strongly leached soils as well as alluvial deposits, indicating also that Th predominates over $\mathrm{U}$ in those areas where both elements are registered in the direct eU and eTh maps, such as the Serra do Carambeí Granite (compare Figs. 4 and 5). The eU/eTh ratio is relatively high only along an area close to the Itaiacoca rocks and in the northeastern part of CGC. The map of the factor $\mathrm{F}(=\mathrm{K} \times \mathrm{eU} / \mathrm{eTh}$ ) repeats what is observed in the eU/eTh map, enhancing those areas where this ratio is high and where, at the same time, $\mathrm{K}$ is also present (i.e., along areas of the CGC bordering the Itaiacoca rocks and in the northeastern CGC regions; cf. both maps in Fig. 5).

The Kd and Ud maps "normalize" respectively elements $\mathrm{K}$ and U against Th (Saunders et al., 1987, 1993, 1994). Therefore, Kd values should enhance positive and negative anomalies observed especially in the $K$ direct map and also in the $F$ factor map, which is the case for the CGC (cf. the respective maps in Figs. 4 and 5). The Ud map, on the other hand, is dependant 

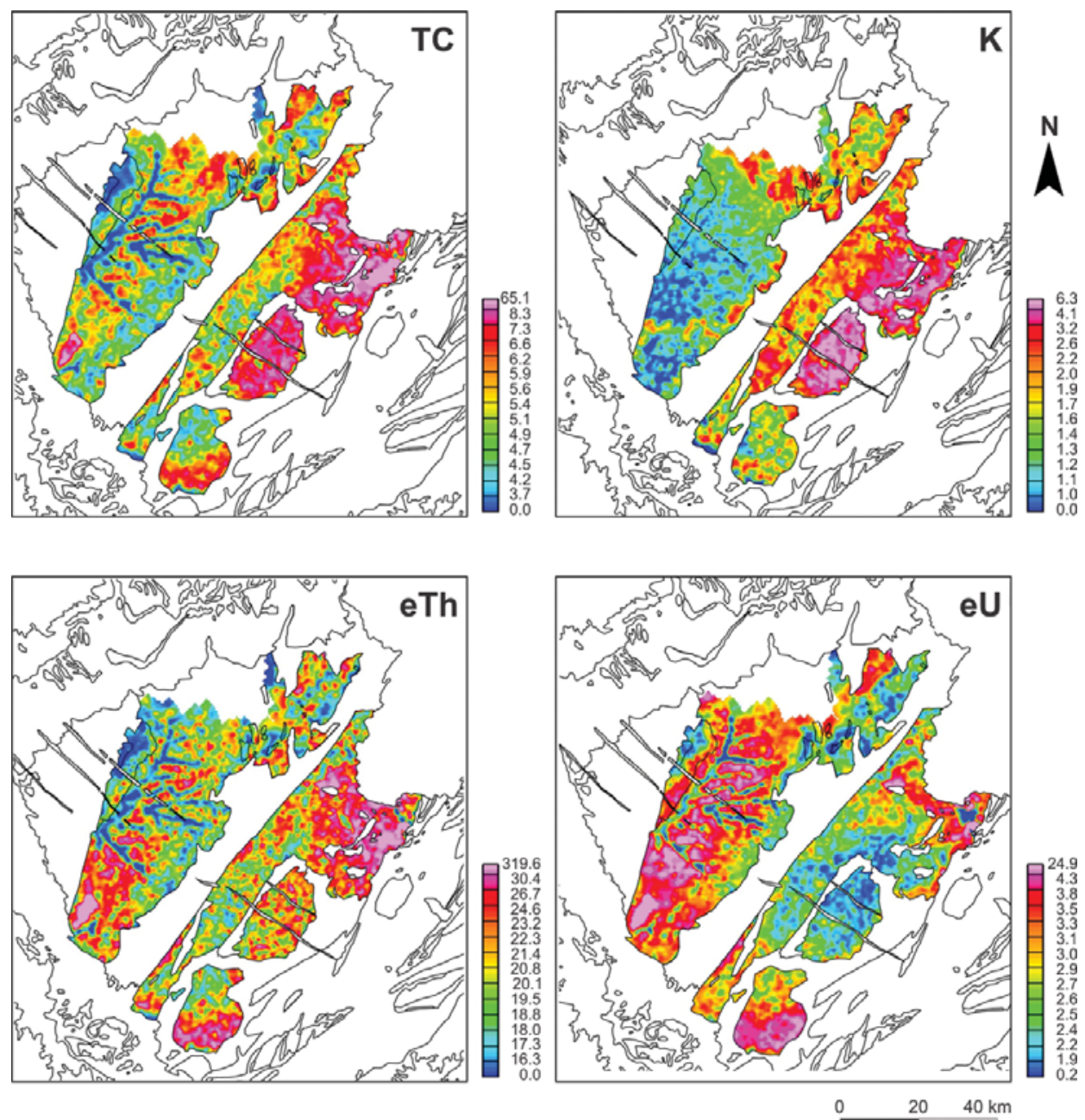

Figure 4 - Gamma-ray spectrometric color-graded maps of TC (Ct), \% K, eU and eTh (in ppm).

on the eU/eTh ratio in granitoids. Therefore, independently of the presence of $\mathrm{K}$ values (which in the CGC are low, on account of strong superficial leaching), the Ud map should repeat the features observed in the eU/eTh map, as clearly shown for the CGC (cf. Figs. 4 and 5). The ternay map K-eU-eTh (Fig. 6) points out the regions with a predominance of one of those elements. Potassium and to a certain extent $\mathrm{U}$ are dominant in the northeastern corner of the CGC, uranium also in the Serra do Carambeí area, whereas Th is spread out along much of the CGC (Fig. 6; compare with the eU, eTh and $\mathrm{K}$ maps in Fig. 4). The dark-grey dendritic pattern in the CGC registers the paucity, or even absence, of all three elements within the alluvial deposits (Fig. 6).

On the whole, gamma-ray surveys in the CGC can not separate clearly, at least on this scale, the several "petrographic domains" recognized during field mapping (Guimarães, 2000), in part because large areas, covered by alluvial and possibly resid- ual soils, are devoid of potassium, leached out by weathering. It should also be noted that most petrographic facies, especially the ones that make up the core of the CGC structure (from north to south, PD 9, 5, 3, 11, 15, and 14, with some undifferentiated areas PD 24; Fig. 3) are made up of calc-alkaline, nondifferentiated granodiorites to monzogranites, chemically very similar and with low or regular contents of accessory minerals, the ones that hold Th and U. On the contrary, more evolved granitoids, richer in those elements, are clearly distinguished in the gamma-ray spectrometric survey (e.g., Th and U patterns for the Serra do Carambeí Granite, in Fig. 4; cf. also the pattern in the differentiated Joaquim Murtinho Granite, in Ferreira et al., 2009). In a similar way, the peraluminous facies exposed in PD 1 (Fig. 3, cf. with pattern in Fig. 4), is clearly marked with lower Th and U responses, in particular because they present, petrographically, lower contents of accessory phases (Guimarães, 2000). 

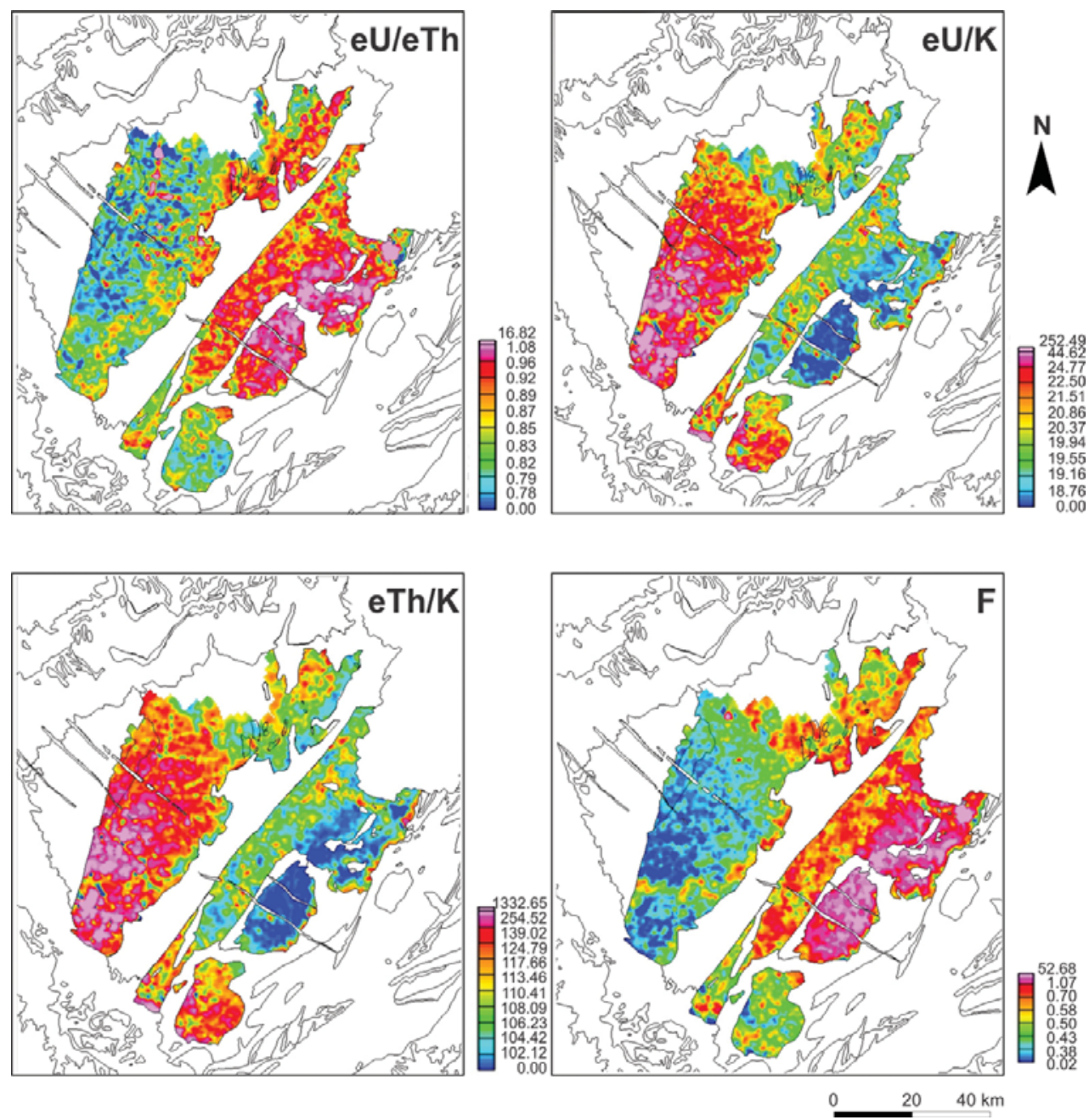

Figure 5 - Gamma-ray spectrometric derived maps: eU/eTh, eU/K and eTh/K ratios and the $\mathrm{F}$ factor ( $=\mathrm{K} \times \mathrm{eU} / \mathrm{eTh}$ ).
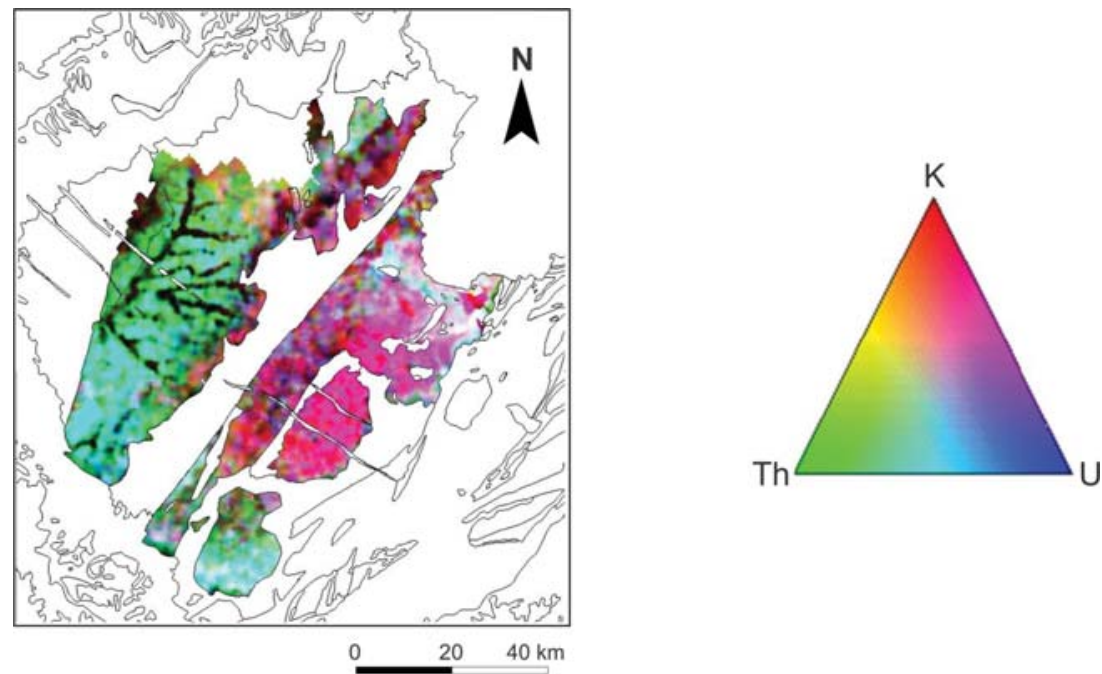

Figure 6 - Gamma-ray spectrometric derived maps: the ternary map K-eTh-eU. 
On the other hand, the patterns observed for the TCGC are better defined, indicating not only a relatively simpler faciological distribution of its different granite types (contrary to CGC, which has a more complex internal structure), but also far better outcrops; here, granites usually appear as fields of boulders. Most of the gamma-ray spectrometric units characterized in Figure 3 present relatively high $\mathrm{K}$ counts, with the exception of units $\mathrm{D}$ and $E$, indicating in this case stronger weathering and/or less favorable outcrop patterns (Fig. 4). The presence of higher values of $\mathrm{K}$ should mark the existence, on the ground, of relatively preserved granite boulders and, therefore, the overlap of $\mathrm{K}$ and Th anomalies, or of $\mathrm{K}$ and $\mathrm{U}$, can be interpreted as an indication of the relative abundance of primary accessory minerals that host $U$ and $T$. Similarly, high $\mathrm{K}$ concentrations coupled with low responses to Th and $U$ should register the relative lack of these accessory minerals. So, the granites in Unit B are clearly enriched in U, less so in Th. Similarly, the São Sebastião Granite (Unit C) is also enriched in U; Th-holding minerals are here less frequent. Both elements are enriched in the southern part of the Conceição Granite (Unit E) or, alternatively, they may be present as "resistant" residual phases in soils (especially Th), as $K$ has been leached out to a certain extent ( $K$ map in Fig. 4).

The eU/K and eTh/K maps for TCGC show low values within units $B$ and $C$, the ones which are characterized by high $K$ concentrations, a pattern that is repeated to a certain extent in Unit $\mathrm{A}$ (Figs. 4 and 5). The eTh and eU maps (Fig. 4) predict that the derived eU/eTh map should present high values in units $A, B$ and $C$, but much lesser ones in the Unit F (Fig. 5) and the Conceição Granite (Unit $D$ and especially Unit $E$ are enriched in both elements). As was also the case for the CGC, the F factor map (Gnojek \& Prichystal, 1985) in the TCGC should repeat the patterns observed in the eU/eTh construction, with increased $\mathrm{F}$ factor figures, since in most cases the values in the $\mathrm{K}$ map are rather high (compare the $\mathrm{K}, \mathrm{eU} / \mathrm{eTh}$, and $\mathrm{F}$ factor maps in Figs. 4 and 5). The so-called Th-K "antagonism", the first element decreasing with an increase in the second, as stated in the literature, does not apply for granites, where a positive correlation is predominant, as routinely shown by chemical determinations for most granite massifs the world over (e.g., Table 4; cf. also Saunders etal., 1987; Dickson \& Scott, 1997; Ulbrich et al., 2009).

The Kd map (not shown here) for TCGC repeats the general features visible in the $\mathrm{K}$ map, but shows an inverse pattern (positive "anomalies" converted into negative ones) in comparison to the $\mathrm{eTh} / \mathrm{K}$ map (it is, however, difficult to interpret, as well as the Ud map, cf. discussion of the CGC pattern). The Ud map (not shown) for the TCGC enhances somewhat the design observed in the eU and the F-factor maps (compare maps in Figs. 4 and 5). The ternary K-eU-eTh representation for the TCGC shows an abundance of $K$ in units $A, B$ and $C$, and of Th and $U$ in units $D$, $E$ and $F$. Several visible whitish areas in the TCGC indicate that locally the three elements, or at least both $\mathrm{Th}$ and $\mathrm{U}$, are present in similar abundances.

The factors Ud and Kd seem to be well suited for the analysis of sedimentary basins holding hydrocarbons (with clear indications of $\mathrm{U}$ and $\mathrm{K}$ anomalies controlled by selective migration of these two elements, cf. Saunders et al., 1994), perhaps also for the case of $K$ enhancement by means of localized hydrothermal alteration (e.g., Pires, 1995). The factors, however, are unsuited for application in the case of basement rocks, which present, to begin with, an intrinsically different concentration of $\mathrm{U}$ and $\mathrm{K}$, which can be further disrupted by selective leaching of $K$ by weathering (sometimes, accompanied by local concentrations of $\mathrm{U}$, cf. the maps shown in Figs. 4 and 5).

\section{SUMMARY AND CONCLUSIONS}

The data listed in Tables 1 and 2 (derived from gamma-ray spectrometric measurements) highlight some of the differences found between the two complexes. Minimum values for $\mathrm{K}$, Th and $\mathrm{U}$ (close to zero) were registered in the CGC, mainly confined within alluvial deposits, which are absent in the TCGC. Maximum values for $\mathrm{K}$ registered by the airborne survey are close to true chemical abundances, as indicated by chemical analysis (cf. Tables 1, 2 and 4). The maximum values for Th and U (Table 1) are very high, thus indicating the presence of local anomalies, which were also registered in ground surveys conducted in search of radioactive deposits, especially centered around the Joaquim Murtinho and Serra do Carambeí granites (cf. bibliography in Guimarães, 2000). Mean values for $\mathrm{K}$ are low for CGC, and higher for TCGC, an indication of stronger weathering and less exposure of granites in the first complex. The mean abundances for Th and $\mathrm{U}$ in both complexes are still high, in contrast with the low values of $\mathrm{K}$ especially in the CGC, thus suggesting that $U$ is not completely leached out and, although mobile to a certain extent, remains at least in part in soils (but not in alluvial deposits). Thorium is a mostly immobile element and should be preserved, or even concentrated, contained in resistant accessory minerals in residual soils; the eTh map in Figure 4 even suggests that a concentration of Thbearing phases occurs in the alluvial sands and soil cover of the central part of the CGC (compare in Fig. 4 the Th pattern to the one shown by $\mathrm{U}$, the last one clearly duplicating the dendritic pattern of the alluvial system). Uranium, in particular, seems to be missing in the alluvial deposits. 
This study shows that a regional gamma-ray spectrometric survey in granitoid rocks can clearly expose differences in contents of $\mathrm{K}$, Th and $\mathrm{U}$, thus allowing a first attempt at a faciological division of large granite units, therefore facilitating posterior field mapping. The CGC case also indicates that leaching of $\mathrm{K}$ under subtropical conditions with heavy seasonal rains is plainly registered in gamma-ray surveys, thus generating a "climatic factor" that has to be taken into consideration during the interpretation of the results.

\section{ACKNOWLEDGMENTS}

The authors thank the Companhia de Recursos Minerais - CPRM, now Serviço Geológico do Brasil, for permission to use the geophysicial data, and Minerais do Paraná S.A. for partially supporting this research. F.J.F. Ferreira and L. Fornazzari Neto also thank CNPq and UFPR for financial and logistic support. $\mathrm{H}$. Prazeres Filho, G.B. Guimarães and H. Ulbrich are grateful for financial support for field and laboratory work granted by Fapesp. V.M.O. Martin and L.S. Alves Szameitat acknowledge support offered by CNPq (student scholarships).

\section{REFERENCES}

BARMP - Brazil Airborne Radiometric Mapping Project. 1997. PWG - Paterson, Grant \& Watson, Limited, CPRM - Serviço Geológico do Brasil, and GSC - Geological Survey of Canadá, Rio de Janeiro. (Digital archive).

BRIGGS IC. 1974. Machine contouring using minimum curvature. Geophysics, 39(1): 39-48.

CPRM - Companhia de Pesquisa de Recursos Minerais. 1978. Projeto Aerogeofísico Serra do Mar Sul, Rio de Janeiro. (Digital archive).

DICKSON BL \& SCOTT KM. 1997. Interpretation of aerial gamma-ray surveys - adding the geochemical factors. AGSO J. Australian Geol. Geophys., 17(2): 187-200.

FERREIRA FJF \& FORNAZZARI NETO L. 2005. Mapas Gamaespectrométricos do Escudo Paranaense. Convênio Mineropar/Funpar/UFPR (unpublished).

FERREIRA FJF, FORNAZZARI NETO L, GUIMARÃES GB \& ULBRICH $H H$. 2005. Contrastes gamaepectrométricos (K, eTh, eU) dos complexos graníticos Cunhaporanga e Três Córregos - PR: análise dos dados do BARMP (Brazil Airborne Radiometric Mapping Project). In: X Congresso Brasileiro de Geoquímica and II Simpósio de Geoquímica dos Países do Mercosul, 2005, Recife/PE (Boletim de Resumos, Recife, SBGq, 2005, v. 1, CD-ROM), 4 pp.

FERREIRA FJF, FRUCHTING A, GUIMARÃES GB, ALVES LS, MARTIN VMO \& ULBRICH HH. 2009. Levantamentos gamaespectrométricos em granitos diferenciados. II: 0 exemplo do Granito Joaquim Murtinho,
Complexo Granítico Cunhaporanga, PR. Geologia USP, Série Científica, São Paulo, 9(1): 55-72. Doi: 10.5327/Z1519-874X2009000100004.

FUCK RA, MARINI OJ \& TREIN E. 1967. Contribuição ao estudo das rochas graníticas do Paraná. In: BIGARELLA JJ, SALAMUNI R \& PINTO VM (Eds.). Geologia do Pré-devoniano e intrusivas subseqüentes da porção oriental do estado do Paraná. Bol. Paranaen. Geoc., 23/25: 183219 .

GNOJEK I \& PRICHYSTAL A. 1985. A new zinc mineralization detected by airborne gamma-ray spectrometry, northern Moravia (Czechoslovakia). Geoexploration, 23: 491-502.

GRASTY RL. 1976. A calibration procedure for an airborne gamma-ray spectrometer. Geological Survey of Canada, Paper 76-16: 1-9.

GRASTY RL, HOLMAN PB \& BLANCHARD YB. 1991. Transportable calibration pads for ground and airborne gamma-ray spectrometers. Geological Survey of Canada, Paper 90-23, 21 pp.

GRASTY RL, SMITH BS \& MINTY BRS. 1997. Developments in the standardization and analysis of airborne gamma-ray data. In: Exploration 97, The 4th Decennial International Conference on Mineral Exploration, Toronto, 1997, $15 \mathrm{pp}$.

GUIMARÃES GB. 1995. 0 Complexo Granítico Cunhaporanga na região de Joaquim Murtinho, Piraí do Sul (PR): caracterização faciológica das rochas granitóides. M.Sc. Dissertation, Instituto de Geociências, Universidade de São Paulo, 144 pp.

GUIMARÃES GB. 2000. As rochas granitóides do Complexo Granítico Cunhaporanga, Paraná: aspectos geológicos, geofísicos, geoquímicos e mineralógicos. Doctorate Thesis, Instituto de Geociências, Universidade de São Paulo, 230 pp.

GUIMARÃES GB, FERREIRA FJF, ULBRICH HHGJ \& FORLIN M. 2001. The Aerogeophysical Project Serra do Mar Sul in the region of the Cunhaporanga Granitic Complex, Paraná, southern Brazil: analysis of the gamma-ray spectrometric survey. Brazilian Journal of Geophysics, 19(1): $3-17$.

IAEA - International Atomic Energy Agency. 1991. Airborne gamma-ray spectrometer surveying. Techn. Report Series, no. 323, Vienna, IAEA, $97 \mathrm{pp}$.

KEMP AIS \& HAWKESWORTH CJ. 2004. Granitic perspective on the generation and secular evolution of the continental crust. In: HOLLAND HD \& TUREKIAN KK (Eds.). Treatise on Geochemistry, v. 3, The Crust. 349410.

MARQUES LS \& ERNESTO M. 2004. 0 magmatismo toleítico da Bacia do Paraná. In: MANTESSO NETO V, BARTORELLIA, CARNEIRO CDR \& BRITO NEVES BB (Eds.). Geologia do Continente Sul-Americano. Beca, São Paulo, 265-279.

MINTY BRS. 1997. The fundamentals of airborne gamma-ray spectrometry. AGSO J. Australian Geol. Geoph., 17(2): 39-50. 
MINTY BRS, LUYENDIK APJ \& BRODIE RC. 1997. Calibration and data processing for airborne gamma-ray spectrometry. AGSO J. Australian Geol. Geoph., 17(2): 51-62.

MISENER DJ, SINCLAIR R \& MOURÃO LMF. 1997. A new Brazil radiometric database generation and application. In: International Congress of the Brazilian Geophysical Society, 5., São Paulo, Expanded Abstracts... SBGf, v. 1, p. 564.

PIRES ACB. 1995. Identificação geofísica de áreas de alteração hidrotermal, Crixás-Guarinos, Goiás. Rev. Bras. Geoc., 25: 61-68.

PRAZERES FILHO HJ. 2000. Litogeoquímica, geocronologia (U-Pb) e geologia isotópica dos complexos graníticos Cunhaporanga e Três Córregos, estado do Paraná. M.Sc. Dissertation, Instituto de Geociências, Universidade de São Paulo, 189 pp.

PRAZERES FILHO HJ. 2005. Caracterização geológica e petrogenética do Batólito Granítico Três Córregos (PR-SP): geoquímica isotópica (Nd$\mathrm{Sr}-\mathrm{Pb}$ ), idades (ID-Tims/Shrimp) e $\delta^{18} 0$ em zircão. Doctorate Thesis, Instituto de Geociências, Universidade de São Paulo, 207 pp., 1 Annex.

PRAZERES FILHO HJ, HARARA OM, BASEI MAS, PASSARELLI CR \& SIGA Jr 0. 2003. Litoquímica, geocronologia U-Pb e geologia isotópica (Sr-Nd-Pb) das rochas graníticas dos batólitos Cunhaporanga e Três Córregos na porção sul do Cinturão Ribeira, Estado do Paraná. Geologia USP, Série Científica, 3: 51-70.

RUDNICK R \& GAO S. 2004. Composition of the continental crust. In: HOLLAND HD \& TUREKIAN KK (Eds.). Treatise on Geochemistry, v. 3, The Crust, 1-64.

SAUNDERS DF, TERRY SA \& THOMPSON CK. 1987. Test of National Uranium Resource Evaluation gamma-ray spectral data in petroleum reconnaissance. Geophysics, 52: 1547-1556.
SAUNDERSDF, BURSON KR, BRANCHJF \& THOMPSON CK. 1993. Relation of thorium-normalized surface and aerial radiometric data to subsurface petroleum accumulations. Geophysics, 58: 1417-1427.

SAUNDERS DF, BRANCH JF \& THOMPSON CK. 1994. Tests of Australian aerial radiometric data for use in petroleum reconnaissance. Geophysics, 59: 411-419.

SAUNITE DM, BELLO RMS, ANDRADE FRD \& SZABÓ GAJ. 2011. Metadolomitos talcificados do Grupo Itaiacoca, Paraná: regime de fluidos e implicações genéticas. Geologia USP, Série Científica, São Paulo, 11(1): 171-187.

SZABÓ GAJ, ANDRADE FRD, GUIMARÃES GB, CARVALHO FMS \& MOYA FA. 2006. As jazidas de talco no contexto da história metamórfica dos metadolomitos do Grupo Itaiacoca, PR. Geologia USP, Série Científica, São Paulo, 5(2): 13-31.

ULBRICH HHGJ, VLACH SRF \& JANASI VA. 2001. 0 mapeamento faciológico em rochas ígneas plutônicas. Rev. Bras. Geoc., 31(2): 163-172.

ULBRICH HH, ULBRICH MNC, FERREIRA FJF, ALVES LS, GUIMARÃES GB \& FRUCHTING A. 2009. Levantamentos gamaespectrométricos em granitos diferenciados. I: Revisão da metodologia e do comportamento geoquímico dos elementos K, The U. Geologia USP, Série Científica, São Paulo, 9(1): 33-53. Doi: 10.5327/Z1519-874X2009000100003.

VLACH SRF, JANASI VA \& VASCONCELLOS ACBC. 1990. The Itu Belt: associated calc-alkaline and aluminous A-type late Brasiliano granitoids in the states of São Paulo and Paraná, southern Brazil. In: Congresso Brasileiro de Geologia, 36., Natal, Proceedings... Natal: SBG, v. 4, 17001711.

\section{NOTES ABOUT THE AUTHORS}

Francisco José Fonseca Ferreira. Graduation in Geology (1970) at the Universidade Federal de Pernambuco. Specialized in Applied Geophysics at the Universidade Federal de Bahia (1974). Master's (1982) and Ph.D. (1991) degrees from the Universidade de São Paulo. Employed as geologist in CPRM (1972-1980) and São Paulo's IPT (1981-1990). Currently, associate professor in the Geology Department at the Universidade Federal do Paraná. Coordinator of the university's Laboratory for Research in Applied Geophysics, acting especially in airborne and land geophysics applied to mineral exploration, groundwater research and environmental aspects.

Luiz Fornazzari Neto. Graduation in Geology at the Universidade Federal do Paraná (1996), with a master's degree from the same university (2001) in Exploratory Geology (SIG applied to gold prospecting). Experience and specialization in projects related to prospecting and management of natural resources (minerals, oil reservoirs, groundwater), in several private enterprises and public companies. At present, partner and director in consulting firms on environmental aspects, active mainly in Paraná state.

Luizemara Soares Alves Szameitat. Graduation in Geology (2006) at the Instituto de Geociências, Universidade de São Paulo. A master's degree (2012) in Geophysics, applied to the study of geotectonic aspects, was obtained at the Faculdade de Geologia, Universidade do Estado do Rio de Janeiro (UERJ). Graduate studies, lato sensu, on Petroleum Geology (2007) at UERJ and Structural Geology (2009) at the Universidade Federal de Ouro Preto. Geologist at Petrobras, since 2007, acting mainly in the field of geophysical "potential methods". 
Gilson Burigo Guimarães. Graduation as a geologist (1988) at the Universidade Federal do Paraná (UFPR), with a master's (1995) and doctorate (2000) degrees from Instituto de Geociências, Universidade de São Paulo, on petrology of granitic rocks (mapping, geochemistry, mineralogy, regional context). Specialization in Exploratory Geology (1988) at UFPR. Since 1991, teaching and research position at the Departamento de Geociências, Universidade Estadual de Ponta Grossa.

Victor Miguel Oliveira Martin. Graduation in Geology (2008) at USP. Specialization and working experience in several aspects of Engineering Geology. Formerly employed as a geologist at Departamento Nacional de Produção Mineral, DNPM, and responsible for several projects dealing with environmental issues. At present, supervision of drilling projects and of projects related to environmental causes, on behalf of the Superintendência Regional da CODESVASF - Cia. de Desenvolvimento dos Vales do São Francisco e do Parnaíba (headquarters in Petrolina, Pernambuco state).

Hélcio Prazeres Filho. Graduation in Geology (1996) at the Universidade Federal do Paraná, with a master's (2000) and doctorate (2005) degrees at the Instituto de Geociências, Universidade de São Paulo, on subjects related to regional geology and geochronology of large granitic massifs in Paraná state. Specialized in search and evaluation of ore deposits of economic interest. Since 2006, consulting geologist and coordinator of mineral prospecting at Votorantim Metais Ltda. (headquarters in São Paulo).

Horstpeter Herberto Ulbrich. Graduation in Geology (1963) at the University of Buenos Aires, Ph.D. at University of California, Berkeley (1973). Teaching and research position at the University of Basel (1972-1973) and research associate at Princeton University (1973-1974). Since 1975, teaching and research position at the Departamento de Mineralogia e Petrologia, Universidade de São Paulo, as associate professor (full professor, 1996). Specialized in geochemistry, mineralogy and igneous petrology. 